\title{
Art as an instrument to understand the difference between information, knowledge and knowing
}

We would like to continue with what we undertook in a previous article (Art as an educational tool in medicine), which was the first one of a series of comments regarding art as a teaching resource in training healthcare professionals. This proposal is based on the power that symbolic language of art has to reflect human dimension. ${ }^{1}$ In this article, the difference between these three concepts will be described in the light of the exemplified analysis of Tim Burton's Big Fish.

During medical practice, doctors -as men and professionals- acquire a wealth of diverse information, which they organize in their minds based on their experience so that it can be used and applied to solve specific problems. In this way, information is translated into knowledge. Eventually, when doctors know how, when and where to apply their knowledge so that it becomes therapeutically effective, knowledge is being translated into knowing. That is, information refers to storing data in a mental database (intra-psychic relationship), knowledge refers to the relationship between such information and a specific aspect of reality (mind-object relationship), and knowing refers to the relationship between knowledge and reality as a whole (mind-object-circumstance relationship).

For this reason, a wise man is not the one with the largest amount of information (scholar) or the one who better disposes of knowledge (technician), but the one who knows how to apply knowledge effectively, that is to say, in the most adequate context (wise man). ${ }^{2-5}$

Thus, for example, the film Big Fish tells the story of Edward Bloom, a man characterized by telling outlandish tales about the events of his life, which frustrates his son (Will) to the point that he stops seeing his father for several years. They remain apart until Will's mother tells him that his father is severely ill.

Father and son reunite, and this gives place for Will to complain to Edward that he does not know who his father actually is because of his tall tales. His father says that he is the Edward in his stories, even if Will does not realize who he is.

Edward's stories involved unusual characters, including an uncatchable female fish that Edward was able to catch once using his wedding ring as bait but which he released when he realized that she was going to give birth on the same day Will was going to be born.

Edward gets worse and is hospitalized. Once in hospital, he asks Will to tell him a story of how his death will be. So Will begins telling a fantastic tale of how he and Edward Bloom escape from the hospital and go to the river, where he meets again all the strange people he knew along his life. Then Will immerses his father into the river and Edward turns into the big fish of his tales. Edward is fascinated by the story, and leaves this world. Will finally understands that his father has always been a blend of fantasy and reality, and that without such fantasy he would have never been who he really was. ${ }^{6,7}$

Edward knew many real and fantastic things about himself (information), but in his tales he always narrated a selection of such real or unreal events (knowledge) because he knew himself and was aware that this was the version of himself that he needed to be happy (knowing), that is, to be the Edward he wanted to be for himself and for others.

In short, introducing art as an educational tool in medicine helps to achieve a better understanding of the marked differences among three concepts: information, knowledge and knowing.

\section{Carlos G. Musso, M.D., and Paula A. Enz, M.D. \\ School of Medicine, Instituto Universitario del Hospital Italiano de Buenos Aires,Argentina}

http:/ /dx.doi.org/10.5546/aap.2015.eng.388

\section{REFERENCES}

1. Musso CG, Enz PA. El arte como instrumento educativo en medicina.Arch Argent Pediatr 2014;112(6):494-5.

2. Musso CG. Obras maestras del arte universal y la medicina: Las tentaciones de San Antonio deHieronymus Bosch (Jeroen van Aken) (1450-1516).Evid Act PractAmbul. En prensa 2015.

3. Comte-Sponville A. La sabiduría consiste en amar la vida. Filosofía hoy 2012;19:16-9.

4. Ferry L. La sabiduría de los mitos. Aprender a vivir II. Buenos Aires; Taurus: 2010.

5. Musso CG, Enz P. Arte y naturaleza humana XIX. Rev Hosp Ital BAires.En prensa 2015.

6. Burton T. Big fish [film]. USA: Columbia Pictures; 2003.

7. Burguera Rozado J. El reencuentro con la eficacia simbólica en Big Fish. 2012. Kindle version. 